\title{
RESEARCH PAPER \\ Meat quality and carcass characteristics of Merino Precoce suckling lambs raised under confinement in the Mediterranean semi-humid dryland of Central Chile
}

\author{
Patricio Pérez ${ }^{1}$, Mario Maino ${ }^{1}$, María Sol Morales ${ }^{1}$, Gerda Tomic ${ }^{2}$, Francisco \\ Aguilera ${ }^{1}$, and Juan Ignacio Egaña ${ }^{1}$ \\ 'FacuItad de Ciencias Veterinarias y Pecuarias, Universidad de Chile, Casilla 2, Correo 15, Santiago, Chile. \\ ${ }^{2}$ FacuItad Tecnológica. Universidad de Santiago de Chile. Avda. Ecuador 3769, Santiago, Chile.
}

\begin{abstract}
P. Pérez, M. Maino, M.S. Morales, G. Tomic, F. Aguilera, and J.I. Egaña. 2012. Meat quality and carcass characteristics of Merino Precoce suckling lambs raised under confinement in the Mediterranean semi-humid dryland of Central Chile. Cien. Inv. Agr. 39(2): 289-298. Twenty-eight Merino Precoce suckling lambs raised under confinement in the Mediterranean semi-humid dryland of Central Chile were studied to evaluate meat quality and major carcass characteristics. Animals were grouped by slaughter weight $(10$ and $15 \mathrm{~kg})$ and sex ( 7 males and 7 females in each weight group). The average commercial and true dressing percentages were 53 and $55 \%$, the average ribeye area was $11.7 \mathrm{~cm}^{2}$, and the average dorsal fat thickness was 1.5 $\mathrm{mm}$. The largest retail yields were those of the leg and shoulder, at 38 and $22 \%$, respectively. The tissue composition of the leg was $58 \%$ muscle, $23 \%$ bone, $12 \%$ fat, $3.6 \%$ residues, and $3 \%$ shrink loss. The tissue composition of the shoulder was $57 \%$ muscle, $23 \%$ bone, $11 \%$ fat, $3.7 \%$ residues and 3.2\% shrink loss. The average chemical composition of the fresh meat was $67 \%$ moisture, $19 \%$ protein, $13 \%$ ether extract, and $1.3 \%$ ash. Sensory panel evaluation indicated that almost all the sensory characteristics were within the ideal range, and the acceptability panel evaluation indicated that $15 \mathrm{~kg}$ lambs produced the most acceptable meat. Slaughter weight had the most significant effect on carcass and meat quality. These results confirm that Merino Precoce suckling lambs yield high-quality carcasses and highly acceptable meat.
\end{abstract}

Key words: Chile, meat quality, suckling lambs.

\section{Introduction}

One important feature of the Chilean sheep farming sector is the almost exclusive use of extensive production systems. Farmers have tried to generate profits from marketing wool and lamb from sheep raised on pastures that are

Received March 21, 2011. Accepted November 6, 2011. Corresponding author: pperez@uchile.cl unsuitable for efficient bovine production. Ovine meat produced for export has managed to thrive under those conditions, in spite of a decline in domestic consumption. The low local consumption of ovine meat may be related to multiple factors, including the organoleptic quality of the meat, its nutritive value and high price (Pérez et al., 2006; Pérez et al., 2007). These issues have not been adequately addressed, impacting demand and, in turn, producer income. 
To reverse the trend of declining demand for ovine meat, the sector must improve the consumer perception of the product. The industry will need to raise market awareness and offer different products, especially lambs of different slaughter weights. Further, it is important to encourage market diversification, enabling product differentiation and value adding. One such strategy may include the production of suckling lambs, a product that plays an important role in various countries in the European Union (Velasco et al., 2000; Osorio et al., 2008; Santos et al., 2008). It is expected that such changes will increase producer income and profitability, substantially enhancing sector development and thus creating a sustainable lamb production system over time.

One breed that could be part of such a scheme is the Merino Precoce, a dual-purpose wool/meatbreed that can be found throughout Central Chile. The adult females weigh approximately 70 to 80 $\mathrm{kg}$, while males weigh approximately 100 to 130 $\mathrm{kg}$. Their lambs, which weigh approximately 4.2 to $4.6 \mathrm{~kg}$ at birth, are usually sold at an age of 3 to 5 months, at which time they weigh between 25 and $35 \mathrm{~kg}$. The objectives of this study were evaluate the effects of slaughter weight and sex on the main carcass and meat characteristics of Merino Precoce suckling lambs.

\section{Materials and methods}

Twenty-eight lambs (14 male and 14 female) weighing an average of $4.81 \pm 0.5 \mathrm{~kg}$, were raised in permanent confinement and fed only on their mothers' milk in the Mediterranean semi-humid dryland of Central Chile. Lambs were born within 15 days of one another from single lambing and from second or third lambing ewes. Dams were fed a complete pellet diet (Pérez et al., 2002). Lambs were assigned to 4 groups according to slaughter weight $(9.5 \pm 0.5$ or $14.4 \pm 1 \mathrm{~kg})$ and sex (male or female). Slaughter weight was reached at $25 \pm 3$ and $32 \pm 6$ days of age, for lambs in the 10 and $15 \mathrm{~kg}$ groups, respectively. Animals were transported to a local commercial slaughterhouse and fasted (water was available ad libitum) for 12 hours prior to slaughter. After weighing, lambs were electrically stunned and slaughtered according to standard procedures. Afterward, the hot carcass weight (including kidney and perirenal fat) was recorded. The gastrointestinal content was estimated as the difference between the full and empty gastrointestinal tract, and empty body weight was estimated as live weight minus gastrointestinal content. Commercial dressing percentage was calculated as the ratio between the carcass weight and live weight times 100 , and true dressing percentage was calculated as the ratio between carcass weight and empty body weight times 100 (Pérez et al., 2002; Pérez et al., 2007).

Carcasses were weighed again three hours after slaughter and then halved longitudinally with a band saw. Each carcass half was then cut into quarters between the $12^{\text {th }}$ and $13^{\text {th }}$ ribs. Fat depth was measured at three-quarters of the distance between the hind end and a line perpendicular to the axis running through the center of the longissimus dorsi muscle (Pérez et al., 2000; Pérez et al., 2001; Pérez et al., 2002). Calipers were used to measure the area of the Iongissimus dorsi muscle at the $12^{\text {th }}$ rib. The carcass quarters were then cut into neck, shoulder, chops, thorax and leg cuts according to the Chilean standard cutting procedure for lambs (Pérez et al., 2002). The cuts from the right halves of the carcasses were dissected to remove bones and tendons (Pérez et al., 2002). The remaining muscle and fat were ground and mixed thoroughly (Pérez et al., 2002), and samples of this mix were taken to determine moisture, nitrogen content, ether extract and ash contents using standard methods (AOAC, 1995). The leg and shoulder from the left halves of the carcasses were packed in polyethylene bags, frozen at $-20^{\circ} \mathrm{C}$, and dissected 2-5 months later. These cuts were dissected following the guidelines of Fisher and de Boer (1994) into four components: muscle, fat (subcutaneous and intermuscular), bones, and residues (lymphatic ganglia, large blood vessels and nerves, tendons, and joint capsules). Each component was weighed on a digital scale with a sensitivity of 0.05 grams. Shrink loss was 
estimated as the difference between the initial and final weight of each piece. This value was then used to calculate the commercial dressing percentage of each of the components (Pérez et al., 2002).

Twelve fillet samples (Psoas mayor, Psoas minor, Iliacus and Quadratus lumborum) of each lamb group were used for sensory evaluation. A panel of 12 trained evaluators performed the preference and acceptability testing according to a method similar to that described by Sañudo et al. (1997a) and Pérez et al. (2002). Before the evaluation, fillets were seasoned with $1.8 \%$ salt and cooked at $120^{\circ} \mathrm{C}$ for 45 minutes. The panel scored the samples on a hedonic scale of 1 to 9 points each for appearance, aroma, color, saltiness, greasiness, fibrosity, texture, flavor, and acceptability and on a scale of 1 to 7 for tenderness and juiciness (Anzaldua - Morales, 1995).

The physical analysis of the meat included:

1) Water holding capacity-a sample is centrifuged at $1074.2 \mathrm{x}$ g for 15 minutes to extract water that is intimately bound to the tissue structures, especially to proteins. Water holding capacity is expressed as the percentage of weight lost (Fernandez et al., 1997; Sañudo et al., 1997a).

2) Emulsification capacity-a measure of the change in electrical resistance produced when phases are inverted, indicating the maximum capacity of proteins to maintain the emulsification of fine drops of oil in a continuous water phase. This represents the amount of oil emulsified per gram of protein (Pérez et al., 2002).

3) Tenderness-measured by shear force tests in a cooked sample of a standard size. Warner-Bratzler blades attached to a Lloyd LR-5K machine were used (Sañudo et al., 1997a; Sañudo et al., 1998).

Finally, for the fatty acid profile, random samples were taken from the perirenal and pelvic fat of three animals per group (Pérez et al., 2002), and the methyl ester contents of the samples were measured using gas-liquid chromatography (Sañudo et al., 1998; Velasco et al., 1999).

The data were analyzed in a $2 \times 2$ factorial analysis of variance with gender, weight and their interaction (gender $\times$ weight) as the factors. Variables measured as percentages were transformed using an arc-sine function (Sokal and Rohlf, 1981).

\section{Results and discussion}

The effects of slaughter weight and sex on the main carcass characteristics and retail yield are shown in Table 1. No significant effects for

Table 1. The effects of slaughter weight and sex on carcass characteristics and commercial cut proportions of Merino Precoce suckling lambs.

\begin{tabular}{|c|c|c|c|c|c|c|c|}
\hline & \multicolumn{7}{|c|}{ Sex (S) and slaughter weight (W) $(\mathrm{kg})$} \\
\hline & \multicolumn{2}{|c|}{ Male } & \multicolumn{2}{|c|}{ Female } & \multirow{2}{*}{ SE } & \multirow{2}{*}{$\mathrm{W}$} & \multirow{2}{*}{$\mathrm{W} \times \mathrm{S}$} \\
\hline & 10 & 15 & 10 & 15 & & & \\
\hline Commercial dressing percentage & 53.1 & 52.7 & 52.0 & 55.3 & 1.4 & & $*$ \\
\hline True dressing percentage & 54.1 & 54.4 & 53.7 & 56.6 & 1.2 & $*$ & \\
\hline Hot carcass weight & 5.4 & 7.9 & 4.9 & 7.6 & 1.8 & $* * *$ & \\
\hline Muscle area $\left(\mathrm{cm}^{2}\right)$ & 10.3 & 13.1 & 10.6 & 12.9 & 2.2 & $* *$ & \\
\hline Fat depth over longissimus dorsi mm & 1.1 & 2.0 & 1.0 & 1.9 & 0.7 & $* * *$ & \\
\hline Leg percentage & 37.9 & 38.0 & 38.6 & 36.4 & 1.2 & & \\
\hline Shoulder percentage & 22.1 & 22.6 & 22.4 & 22.0 & 0.7 & & \\
\hline Thorax percentage & 15.9 & 20.0 & 15.7 & 19.6 & 1.9 & $* * *$ & \\
\hline Chops percentage & 16.9 & 13.6 & 16.1 & 13.4 & 1.7 & $* * *$ & \\
\hline Neck percentage & 6.0 & 5.0 & 5.9 & 6.9 & 2.0 & & \\
\hline Tail percentage & 1.1 & 1.0 & 1.1 & 1.1 & 0.8 & & \\
\hline
\end{tabular}

$* \mathrm{P} \leq 0.05 ; * * \mathrm{P} \leq 0.01 ; * * * \mathrm{P} \leq 0.01$. SE: Standard Error. 
sex on carcass characteristics were found. As expected given the approximately $50 \%$ difference between the two weights studied, slaughter weight had a significant effect on retail yield and carcass characteristics, but it did not affect the commercial dressing percentage. However, the $\mathrm{W} \times \mathrm{G}$ interaction was significant. These results are consistent with those reported by Sañudo et al. (1997a), Cañeque et al. (1999), and Pérez et al. (2002). Hot carcass weights were comparable to those found for lambs of different breeds slaughtered at comparable weights, such as Suffolk Down (Pérez et al., 2002) and Manchega (Ruiz de Huidobro and Cañeque, 1993a; Lauzurica et al., 1999). The retail yields and dressing percentages of suckling lambs were high compared to those of heavier lambs, most likely because suckling lambs had underdeveloped rumen (Cañeque et al., 1999). Dressing percentages varied from 52 to $55.3 \%$ in females at 10 and $15 \mathrm{~kg}$, respectively, indicating that dressing percentage increased with slaughter weight (Velasco et al., 2000; Santos et al., 2007). These values were somewhat lower than those reported by Lauzurica et al. (1999) for Manchega lambs, but similar to those reported by Pérez et al. (1993) for Manchega lambs and by Pérez et al. (2002) for Suffolk Down lambs, all slaughtered at similar weights. For male lambs, the average ribeye area varied from $10.29 \mathrm{~cm}^{2}$ to $13.14 \mathrm{~cm}^{2}$ at 10 and $15 \mathrm{~kg}$, respectively. Slaughter weight had a significant effect on this parameter; the area increased with slaughter weight. These results support the findings of Kempster et al. (1982) and Sents et al. (1982). Osorio et al. (1997) found ribeye areas of 10.62 to $10.69 \mathrm{~cm}^{2}$ in male and female Corriedale lambs slaughtered at 27.6 to $29.6 \mathrm{~kg}$, indicating that Merino Precoce suckling lambs show desirable carcass characteristics for meat production.

Dorsal fat thickness varied from 1.0 to $2.0 \mathrm{~mm}$ in females of $10 \mathrm{~kg}$ and males of $15 \mathrm{~kg}$, respectively. Cañeque et al. (1997) observed a fat thickness of 1.53 and $2.54 \mathrm{~mm}$ in Talaverana suckling lambs slaughtered at 10 and $14 \mathrm{~kg}$, respectively. Although those values are larger than those reported here, both show a significant increase in fat thickness with slaughter weight. Ruiz de Huidobro and Cañeque (1993b) reported a $2.28 \mathrm{~mm}$ fat thickness in Manchega suckling lambs slaughtered at $15 \mathrm{~kg}$.

The analysis of the retail yield showed that shoulder and leg cuts represent $60 \%$ of the carcass. This is relevant as their high meat content makes them the most valuable cuts. Statistical analysis showed significant main effects for slaughter weight on thorax and chops percentages. Cañeque et al. (1999) found that there was a significant effect $(\mathrm{P} \leq 0.01)$ of slaughter weight on the percent rib retail yield in lambs slaughtered at 10 and $14 \mathrm{~kg}$. Females in that study showed a greater proportion of rib meat and a lower proportion of back and neck meat. These researchers also reported that leg cuts varied from 33.74 to $33.42 \%$ and back cuts varied from 20.12 to $19.64 \%$ in 10 and $14 \mathrm{~kg}$ lambs, respectively. The differences between our results and those reported elsewhere may be caused to a certain extent by the different techniques used to obtain commercial cuts.

Table 2 shows the effect of slaughter weight and sex on the anatomical composition of the shoulder and leg. There was a significant effect of slaughter weight on both the bone and fat percentages in shoulders and legs. The anatomical compositions of the shoulder and leg cuts were similar. Pérez et al. (2002) found somewhat lower composition values for these cuts in Suffolk Down suckling lambs, while Aparicio et al. (1986) reported higher percentages of muscle tissue in the shoulder, leg, and loin cuts of Merino lambs. Ruiz de Huidobro and Cañeque (1994) reported 61\% muscle in shoulder cuts and $60 \%$ in leg, values that are slightly greater than those reported here. These differences may be due to different measurement techniques or to inherent differences in muscle growth rates among these breeds. These two cuts showed very similar percentages of bone. The lighter slaughter weight group had significantly larger percentages of bone in both shoulder and leg cuts, similar to the results reported by Santos et al. (2007) for "Borrego Terrincho-PDO" 
Table 2. The effects of slaughter weight and sex on the anatomical composition of the shoulder and leg of Merino Precoce suckling lambs.

\begin{tabular}{|c|c|c|c|c|c|c|}
\hline & \multicolumn{5}{|c|}{ Sex and slaughter weight $(\mathrm{kg})$} & \multirow{3}{*}{$\begin{array}{c}\text { Slaughter } \\
\text { weight } \\
\text { (W) }\end{array}$} \\
\hline & \multicolumn{2}{|c|}{ Male } & \multicolumn{2}{|c|}{ Female } & \multirow[b]{2}{*}{ SE } & \\
\hline & 10 & 15 & 10 & 15 & & \\
\hline \multicolumn{7}{|l|}{ Shoulder } \\
\hline Muscle & 58.1 & 56.5 & 57.9 & 56.3 & 1.4 & \\
\hline Bone & 25.5 & 21.5 & 24.1 & 20.9 & 2.2 & $* *$ \\
\hline Fat & 9.9 & 14.6 & 10.3 & 10.8 & 4.5 & $* *$ \\
\hline Residues & 3.5 & 4.1 & 3.8 & 3.5 & 2.1 & \\
\hline Losses & 2.9 & 3.2 & 3.9 & 2.6 & 2.8 & \\
\hline \multicolumn{7}{|l|}{ Leg } \\
\hline Muscle & 58.4 & 58.4 & 59.2 & 57.2 & 1.4 & \\
\hline Bone & 25.7 & 21.7 & 24.5 & 21.1 & 1.8 & $* * *$ \\
\hline Fat & 9.9 & 13.2 & 9.3 & 15.4 & 3.7 & $* * *$ \\
\hline Residues & 3.1 & 3.5 & 4.2 & 3.4 & 1.9 & \\
\hline Losses & 2.9 & 3.3 & 2.8 & 2.9 & 2.0 & \\
\hline
\end{tabular}

$* * \mathrm{P} \leq 0.01 ; * * * \mathrm{P} \leq 0.001 . \mathrm{SE}:$ Standard Error.

suckling lambs slaughtered at different weights. This is most likely due to the tendency of bone mass to decrease as live weight and carcass weight increase (Pérez et al., 2002; Velasco et al., 2000).

There was a significant effect of slaughter weight on percent fat in both groups, with $15 \mathrm{~kg}$ animals showing larger fat percentages. This finding is supported by Velasco et al. (2000) and Pérez et al. (2002), who reported that fat typically exhibits greater development than other anatomical components as the animal grows. The fat content ranged from 9.93 to $14.64 \%$ for shoulder cuts and from 9.26 to $15.41 \%$ in the leg. These percentages were lower than those reported by Pérez et al. (2002) for Suffolk Down suckling lambs, suggesting that fat content varies in different anatomical cuts and breeds.

There were no significant effects for gender or gender $\times$ weight on the anatomical composition studied. Shrink loss was also unaffected by all measured variables and was comparable to those reported by Pérez et al. (2002) in Suffolk Down suckling lambs for both shoulder and leg cuts. The effects of slaughter weight and sex on the ratios between anatomical components for leg and shoulder cuts of the carcasses are shown

Table 3. The effects of slaughter weight and sex on the main ratios between the anatomical components of the shoulder and leg of Merino Precoce suckling lambs.

\begin{tabular}{|c|c|c|c|c|c|c|}
\hline & \multicolumn{6}{|c|}{ Sex and slaughter weight $(\mathrm{kg})$} \\
\hline & \multicolumn{2}{|c|}{ Male } & \multicolumn{2}{|c|}{ Female } & \multirow[b]{2}{*}{ SE } & \multirow{2}{*}{$\begin{array}{c}\text { Slaughter } \\
\text { weight (W) }\end{array}$} \\
\hline & 10 & 15 & 10 & 15 & & \\
\hline \multicolumn{7}{|l|}{ Shoulder } \\
\hline Muscle/bone & 2.1 & 2.6 & 2.3 & 2.7 & 0.58 & \\
\hline Muscle + fat/bone & 2.6 & 3.3 & 2.7 & 3.6 & 0.8 & $* *$ \\
\hline Muscle/fat & 6.3 & 4.3 & 7.6 & 3.6 & 2.9 & $* *$ \\
\hline \multicolumn{7}{|l|}{ Leg } \\
\hline Muscle/bone & 2.1 & 2.9 & 2.3 & 2.9 & 0.52 & $* * *$ \\
\hline Muscle + fat/bone & 2.9 & 3.4 & 2.9 & 3.6 & 0.56 & $* *$ \\
\hline Muscle/fat & 6.6 & 4.7 & 7.6 & 3.9 & 2.7 & $* *$ \\
\hline
\end{tabular}

$* * \mathrm{P} \leq 0.01 ; * * * \mathrm{P} \leq 0.001$. SE: Standard Error. 
in Table 3. There were significant effects for slaughter weight on all of the ratios analyzed in both shoulder and leg cuts, except the muscle/ bone ratio in the shoulder. Sex and the interaction between weight and sex had no significant effect on the ratios. Heavier animals showed greater values for all ratios except muscle/fat because fat percentage varied directly with slaughter weight.

The average muscIe+fat/bone values were 3.04 and 3.18 for the shoulder and leg, respectively. These values were similar to those reported by Pérez et al. (2002) for Suffolk Down suckling lambs. The muscle/bone ratio in the Merino Precoce lambs was 2.43 for the shoulder and 2.54 for the leg cuts. In Manchega suckling lambs, this value was measured as 2.7 for the shoulder and 2.8 for leg cuts (Ruiz de Huidobro and Cañeque, 1994), greater than the values reported here. In general, more desirable anatomical component ratios were found in leg cuts, a finding consistent with studies of Suffolk Down (Pérez et al., 2002) and Suffolk Down $\times$ Corriedale suckling lambs (Tabilo, 2001).

Table 4 shows the effects of slaughter weight and sex on the chemical composition of the meat of suckling lambs. Statistical analysis revealed a significant effect of slaughter weight on all variables studied $(\mathrm{P} \leq 0.05)$; average moisture, protein and ash content were greater in the $10 \mathrm{~kg}$ animals, and fat was greater in the $15 \mathrm{~kg}$ animals.
These results contrast with those reported by Santos et al. (2007), who found that only weight affected fat percentage in meat from "Borrego Terrincho-PDO" lambs slaughtered at 8 to $11 \mathrm{~kg}$ live weight. For Latxa suckling lambs (Beriain et al., 1993) and "Borrego Terrincho-PDO" lambs (Santos et al., 2007), values of $75 \%$ moisture, $21 \%$ protein, 1.8 to $2.3 \%$ fat, and 1 to $1.1 \%$ ash have been reported; these values are greater than those reported here, except for fat content. The chemical composition of the suckling lambs studied here indicates that the product has a satisfactory nutritive value.

The effects of slaughter weight and sex on the organoleptic qualities of the meat are presented in Table 5. The only significant effect is that of slaughter weight on flavor, which is consistent with the findings reported by Pérez et al. (2002) for Suffolk Down suckling lambs. Sañudo et al. (1993) however, found that juiciness increased with slaughter weight as well. In a study by Ruiz de Huidobro et al. (1998) using lambs slaughtered at 10 and $12 \mathrm{~kg}$ live weight, the sensory evaluation panel was unable to detect any differences for sex or slaughter weight. Of the two variables analyzed, slaughter weight and sex, only the latter had a significant effect $(\mathrm{P} \leq 0.05)$ on the acceptability of the meat (males $85.4 \%$ and females 93.8\%). The high percentage of acceptable meat is noteworthy and is consistent with reports by Pérez et al. (2002) and Tabilo (2001).

Table 4. The effects of slaughter weight and sex on the chemical composition of Merino Precoce suckling lamb meat.

\begin{tabular}{|c|c|c|c|c|c|c|}
\hline & \multicolumn{5}{|c|}{ Sex and slaughter weight $(\mathrm{kg})$} & \multirow{3}{*}{$\begin{array}{c}\text { Slaughter } \\
\text { weight } \\
\text { (W) }\end{array}$} \\
\hline & \multicolumn{2}{|c|}{ Male } & \multicolumn{2}{|c|}{ Female } & \multirow[b]{2}{*}{$\mathrm{SE}$} & \\
\hline & 10 & 15 & 10 & 15 & & \\
\hline Moisture & 70.6 & 63.9 & 69.3 & 62.9 & 2.66 & $* * *$ \\
\hline Protein & 19.8 & 18.0 & 19.7 & 18.8 & 0.81 & $* * *$ \\
\hline Ether extract & 8.6 & 16.8 & 10.3 & 16.6 & 4.7 & $* * *$ \\
\hline Ash & 1.3 & 1.2 & 1.4 & 1.2 & 0.40 & * \\
\hline
\end{tabular}

$* \mathrm{P} \leq 0.05 . * * \mathrm{P} \leq 0.01 .{ }^{*} * \mathrm{P} \leq 0.001$. SE: Standard Error. 
The physical properties of meat did not differ based on sex, slaughter weight or interaction ( $P$ $>0.05$ ). This finding is consistent with reports by Pérez et al. (2002), who found no differences in these properties among Suffolk Down suckling lambs. However, in Aragonesa lambs, Sañudo et al. (1993) found differences in texture for 8 and $10 \mathrm{~kg}$ carcasses. Vergara and Gallego (1999) obtained similar results for $22 \mathrm{~kg}$ Manchega lambs. The values reported in the last two studies were markedly lower than those reported here. This discrepancy may be due to differences in the handling of the samples before analysis; for example, freezing shortens the muscle fibers (Warris, 2000; Pérez et al., 2002). Wheeler et al. (1997) highlight the divergent texture results obtained by different investigators and comment on the importance of a standardized protocol. Emulsification capacity is difficult to compare across studies due to a lack of standardization in the procedures used to prepare the samples, inconsistencies in terminology, and lack of control materials (Fernandez et al., 1997; Sañudo et al., 1997b; Horcada et al., 1997).

According to the fatty acid profile taken from pelvic and renal fat, palmitic and stearic acid made up approximately $44 \%$ of the samples, similar to the range of results obtained by
Juarez et al. (2010) for the kidney knobs of lambs from different Spanish breeds. In Latxa suckling lambs, Beriain et al. (1993) reported $22.25 \%$ palmitic acid, while Juarez et al. (2010) found 19.1\% C16:0 in Spanish Merino unweaned lambs, somewhat similar to the values reported here. Meanwhile, for stearic acid, Beriain et al. (1993) and Juarez et al. (2010) reported 11.68 and $21.9 \%$, respectively; the lower results are similar to those obtained in this study. In terms of unsaturated fatty acids, oleic acid made up $35 \%$ of the sample. Beriain et al. (1993) and Chasco et al. (1995) found values of approximately $46 \%$ in Latxa lambs. Of the essential fatty acids, linoleic acid varied form 3.2 to $8.0 \%$, and linolenic acid varied from 0.3 to $1.9 \%$. Beriain et al. (1993) also reported values within these ranges. The suckling lambs' fat deposits showed a high proportion of myristic and palmitic acids, which are abundant in sheep's milk (Bas and Morand-Fehr, 2000; Velasco et al., 2000), the sole nutritional source of the suckling lambs until sacrifice.

Overall, the carcasses presented satisfactory retail yield and dressing percentages. Only slaughter weight had significant effects on some of the variables studied. The highest percentage of retail cuts came from the leg, shoulder, thorax,

Table 5. Sensory score evaluations of Merino Precoce suckling lamb meat.

\begin{tabular}{lcccccc}
\hline & \multicolumn{4}{c}{ Sex and slaughter weight $(\mathrm{kg})$} & \\
\cline { 2 - 3 } \cline { 5 - 6 } \cline { 5 - 6 } Appearance & 10 & 15 & & \multicolumn{2}{c}{ Female } & Ideal Score \\
\cline { 2 - 3 } Texture & 6.4 & 7.0 & & 6.3 & 6.8 & $5.5-9$ \\
Color & 6.3 & 6.3 & & 6.2 & 6.6 & $5.5-9$ \\
Flavor & 5.6 & 5.0 & & 4.8 & 5.3 & 5 \\
Salted & $5.3 \mathrm{a}$ & $5.6 \mathrm{~b}$ & & $5.1 \mathrm{a}$ & $6.0 \mathrm{~b}$ & 5 \\
Taste & 4.9 & 4.7 & & 4.8 & 5.2 & 5 \\
Fibrous & 5.9 & 5.5 & & 5.3 & 5.6 & 5 \\
Tenderness & 5.0 & 5.4 & & 5.8 & 4.7 & 5 \\
Fattiness & 3.7 & 3.7 & & 4.0 & 3.8 & $3-4$ \\
Juiciness & 5.3 & 4.6 & & 4.9 & 4.5 & $3-4$ \\
\hline
\end{tabular}

Different letters in a row indicate significant differences $(\mathrm{P} \leq 0.05)$. 
and chops. The ratio of edible to inedible anatomical components in shoulder and leg cuts was approximately 3:1. Chemical composition varied only according to slaughter weight and was better in animals with $10 \mathrm{~kg}$.

The meat of the suckling lambs was highly acceptable and almost all sensory score characteristics were within the ideal range. The fatty acid profile showed a high proportion of saturated fatty acids.

\section{Acknowledgments}

This research was funded by the Fundación para la lnnovación Agraria (FIA), Chile, project C-97-2-P-008.

\section{Resumen}

P. Pérez, M. Maino, M.S. Morales, G. Tomic, F. Aguilera y J.I. Egaña. 2012. Calidad de carne y características de la canal de corderos lechales Merino Precoz criados en confinamiento en la zona Mediterránea semi-húmeda del secano costero central de Chile. Cien. Inv. Agr. 39(2): 289-298. Con el propósito de estudiar las principales características de la canal y de la carne de corderos lechales de la raza Merino Precoz. Se analizaron 28 corderos, los que se agruparon por peso vivo al sacrificio (10 versus 15 kilos) y sexo ( 7 hembras y 7 machos en cada grupo de sacrificio). Los principales resultados obtenidos fueron: Porcentaje de rendimiento comercial y verdadero de la canal, 53\% y 55\%, respectivamente. Área del ojo del lomo promedio, $11,7 \mathrm{~cm}^{2}$, Promedio de espesor de grasa dorsal, 1,5 $\mathrm{mm}$. Los mayores rendimientos al desposte comercial, correspondieron a la pierna y a la espaldilla, con $38 \%$ y $22 \%$, respectivamente. La composición promedio al desposte tisular de la pierna fue de $58 \%$ para el músculo, $23 \%$ para hueso, $12 \%$ de grasa, $3.6 \%$ para residuos y $3 \%$ para pérdidas por deshidratación. El promedio para la composición tisular de espaldilla fue de 57, 23, 11, 3,7 y $3,2 \%$, respectivamente. La composición química promedio para la carne fresca fue de $67 \%$ para humedad, $19 \%$ para proteínas, $13 \%$ para extracto etéreo y 1,3\% para cenizas. La evaluación sensorial de la carne, indicó que la mayoría de las características analizadas fueron cercanas al óptimo y que la aceptabilidad de la carne fue mayor para los corderos sacrificados con $15 \mathrm{~kg}$. El peso de sacrificio tuvo el mayor efecto sobre las características de canal y de carne. Estos resultados confirmaron que los corderos de la raza Merino Precoz produjeron canales y carne de alta calidad.

Palabras clave: Calidad de canal, calidad de carne, Chile, corderos lechales.

\section{References}

AnzaIdua-MoraIes, A. 1995. La evaluación sensorial de los alimentos en la teoría y Ia práctica. Edit. Acribia, Zaragoza. España. 191 pp.

AOAC. 1995. Chapter 39: Meat and meats products. In: Association of Official Analytical Chemistry (AOAC). Official methods of analysis. 16th Ed. Arlington. Virginia, USA. p. 39.1-39.-23.
Aparicio, F., J.Tovar, and V. Domenech. 1986. Relación de los tejidos óseo, muscular y graso de canales de cordero raza Merino. Archivos de Zootecnia 35: 173-181.

Bas, P., and P. Morand-Fehr. 2000. Effect of nutritional factors on fatty acid composition of lamb fat deposits. Livestock Production Science 64: 61-79.

Beriain, M. J,A. Purroy, A. Horcada, J. Chasco, G. Lizaso, J.A. Mendizabal, and F.J. Mendizabal. 
1993. Calidad y composición de Ia carne de corderos de las razas Latxa y Raza Aragonesa. ITEA Vol. extra $\mathrm{N}^{\circ} 12$. Tomo 11. p. 651-653.

Cañeque, V., J.L. Sancha, M.A. Cantero, S. Velasco, F. Ruiz de Huidobro, D. López, S. Lauzurica, C. Pérez, and C. García. 1997. Efecto del peso de sacrificio sobre el engrasamiento de la canal en corderos lechales de la raza Talaverana. ITEA Vol. extra $\mathrm{N}^{\circ}$ 18. Tomo 11. p. 709-711.

Cañeque, V., C. Pérez, S. Velasco, M.T. Diaz, S. Lauzurica, F. Ruiz de Huidobro, and J. Gayán. 1999. Parametros productivos del lechal Manchego 111. Despiece y composición tisular. ITEA Vol. extra N²0 Tomo I. p. 110-112.

Chasco, J., M.J. Beriain, A. Purroy, A. Horcada, A. Hidalgo, G. Lizaso, J.A. Mendizabal, F.J.Mendizabal, and B. Soret. 1995. Efecto del sexo sobre Ia composición de los ácidos grasos de los diferentes depósitos lipídicos de corderos de las razas, Latxa y raza Aragonesa. ITEA Vol. extra $\mathrm{N}^{\circ} 16$ Tomo 1l. p. 645-647.

Fernández, B., M. López, R. Sueiro, M. Vallejo, and L. Sánchez. 1997. Calidad de la carne de cordero de raza ovina Gallega. ITEA Vol. extra $\mathrm{N}^{\circ} 18$. Tomo 11. p. 718-720.

Fisher, A.V., and de H. Boer. 1994. The- EAAP standard method of sheep carcass assessment. Carcass measurements and dissection procedures. Livestock Production Science 38: 149-159.

Hall, G.M. 1996. Methods of testing protein funcionality. Champman \& Hall, London. 265 pp.

Horcada, A., A. Purroy, M.J. Beriain, J. Chasco, C. Gorraiz, M. Alzueta, and J.A. Mendizabal. 1997. Efecto del peso de sacrificio sobre la calidad de la carne de los corderos de las razas Lacha y Aragonesa. ITEA Vol. extra $\mathrm{N}^{\circ} 18$ Tomo 11. p. 715-717.

Juarez, M., A. Horcada, J.M. Alcalde, N. Aldai, O. Polvillo, M. Valera, and A. Molina. 2010. Short communication. Fatty acid composition of lamb fat depots as an origin discriminator. Spanish. Journal of Agricultural Research 8: 976-980.

Kempster, A., A. Cuthbertson, and G. Harrington. 1982. Carcass evaluation in livestock breeding, production and marketing. Granada Publishing, St. Albans, UK. 153 pp.
Lauzurica, S., C. Pérez, V. Cañeque, F. Ruiz de Huidobro, S. Velasco, M.T. Díaz, and J. Gayán. 1999. Parámetros productivos del Iechal Manchego I. Características al sacrificio. ITEA Vol. extra $\mathrm{N}^{\circ} 2 \mathrm{O}$ Tomo I. p. 104-106.

Osorio, J.C., G.A. Maria, M. Pimentel, and P. Jardim. 1997. Efecto del sexo sobre Ia producción de carne de corderos de raza Corriedale en Brasil. VII Jornadas sobre Producción Animal. ITEA Vol. extra $\mathrm{N}^{\circ}$ 18. Tomo I. p. 131-133.

Osorio, M.T., J.M. Zumalacárregui, E.A. Cabeza, A. Figueroa, and J. Mateo. 2008. Effect of rearing system on some meat quality traits and volative compounds of suckling lamb meats. Small Ruminant Research 78: 1-12.

Pérez, J.1., L. Gallego, V. Gómez, J. Otal, M.T. Osorio,and C. Sañudo. 1993. Efecto del tipo de destete, tipo de pasto, sexo y peso de la canal en canales de corderos de raza Manchega. ITEA Vol. extra $\mathrm{N}^{\circ} 12$. Tomo II. p. 649-650.

Pérez, P., M. Maino, R. Guzmán, A. Vaquero, C. Kobrich, and J. Pokniak. 2000. Carcass characteristics of llama (Lama glama) reared in Central Chile. Small Ruminant Research 37: 93-97.

Pérez, P., M. Maino, M.S. Morales, and A. Soto. 2001. Effect of goat milk and milk substitutes and sex on productive parameters and carcass composition of Creole kids. Small Ruminant Research 42: 87-93.

Pérez, P., M. Maino, G. Tomic, E. Mardones, and J. Pokniak. 2002. Carcass characteristics and meat quality of Suffolk Down suckling lambs. Small Ruminant Research 44: 233-240.

Pérez, P., M. Maino, G. Tomic, C. Köbrich, M.S. Morales, and J. Pokniak. 2006. Calidad de carne de corderos lechales del cruce Suffolk Down x Merino Precoz Alemán: Efecto del peso de sacrificio y sexo. Archivos de Zootecnia 55: 171-182.

Pérez, P., M. Maino, M.S. Morales, C. Köbrich,C. Bardón, and J. Pokniak. 2007. Gender and slaughter weight effects on carcass quality traits of suckling lambs from four different genotypes. Small Ruminant Research 70: 124-130.

Ruiz de Huidobro, F., and V. Cañeque. 1993a. Producción de carnes en corderos de raza Manchega. I: Estudio de los rendimientos en canal, de las 
pérdidas en el matadero y de la importancia de los despojos. Investigación Agraria. Producción y Sanidad Animal 8: 111-125.

Ruiz de Huidobro, F., and V. Cañeque. 1993b. Producción de carne en corderos de raza Manchega. Il. Conformación y estado de engrasamiento de la canal y proporción de piezas en distintos tipos. Investigación Agraria. Producción y Sanidad Animal 8: 233-245.

Ruiz de Huidobro, F., and V. Cañeque. 1994. Producción de Carne en Corderos de Raza Manchega. III. Composición tisular de las canales y de las piezas. Investigación Agraria, Producción y Sanidad Animal 9: 57-69.

Ruiz de Huidobro, F., J.L. Sancha, D. López, M.A. Cantero, V. Cañeque, S. VeIasco, C. Manzanares, J. Gayán, S. Lauzurica, and C. Pérez. 1998. Características instrumentales y sensoriales de la carne de corderos lechales de la raza Talaverana. Investigación Agraria Producción y Sanidad Animal 13: 21-29.

Santos, V.A.C., S.R. Silva, E.G. Mena, and J.M.T. Azevedo. 2007. Live weight and sex effects on carcass and meat quality of "Borrego-TerrinchoPDO" suckling lambs. Meat Science 77: 654661.

Santos, V.A.C., S.R. Silva, and J.M.T. Azevedo. 2008. Carcass composition and meat quality of equally mature kids and lambs. Journal of Animal Science 86: 1943-1950.

Sañudo, C., Y. Sierra, M.T. Osorio, N.J. Alcalde, E. Ramos, and P. Santolaria. 1993. Evolución de Ia calidad de Ia carne con el aumento de peso de la canal $(7,4-15,5 \mathrm{~kg})$ en Ia raza Aragonesa. ITEA Vol. extra N ${ }^{\circ} 12$. Tomo II. p. 654-656.

Sañudo, C., M.M. Campo, I. Sierra, G.A. María, J.L. Olleta, and P. Santolaria. 1997a. Breed effect on carcass and meat quality of suckling lambs. Meat Science 4: 357-365.

Sañudo, C., M. Enser, M.M. Campo, G.R. Nute, G.A. María, I. Sierra, and J.D. Wood. 1997b. Calidad de la grasa en canales de cordero españolas y británicas. Relaciones entre la composición de ácidos grasos de la grasa intramuscular y las car- acterísticas sensoriales de Ia carne para el gusto español y británico. ITEA Vol. extra $\mathrm{N}^{\circ} 18$. Tomo 11. p. 724-726.

Sañudo, C., I. Sierra, J.L. Olleta, L. Martin, M.M. Campo, P. Santolaria, and J.D. Woods. 1998. Influence of weaning on carcass quality, fatty acid composition and meat quality in intensive lamb production systems. Animal Science 66: 175-187.

Sents, A.E., L.E. Walters, and J.V. Whiteman. 1982. Performance and carcass characteristics of ram lambs slaughtered at different weights. Journal of Animal Science 55: 1360-1369.

Sokal, R., and F. Rohlf. 1981. Biometry. The principles and practice of statistics in biological research. Second ed. W. H. Freeman and Co. New York. 859 pp.

Tabilo, L. 2001. Características de Ia composición anatómica de la canal y calidad de la came de corderos Iechales híbridos de Suffolk Down por Corriedale efecto del sexo y peso de sacrificio. Memoria Med. Vet. Facultad de Ciencias Veterinarias y Pecuarias. Universidad de Chile. Santiago, Chile. 68 pp.

Vergara, H., and L. Gallego. 1999. Efecto del peso de sacrificio y el sexo en la calidad de la carne de corderos de raza Manchega. ITEA Vol. extra 20 $\mathrm{N}^{\circ}$ 1. p. 140-142.

Velasco, S., V. Cañeque, S. Lauzurica, M.T. Diaz, F. Ruiz de Huidobro, C. Pérez, and C. Manzanares. 1999. Parámetros productivos del lechal Manchego. V. Composición en ácidos grasos. ITEA Vol. extra $\mathrm{N}^{\circ} 20$ Tomo I. p. 116-118.

Velasco, S., S, Lauzurica, V. Cañeque, C. Pérez, F. Huidobro, C. Manzanares, and M.T. Díaz. 2000. Carcass and meat quality of Talaverana breed suckling lambs in relation to gender and slaughter weight. Animal Science 70: 253-263.

Warris, P.D. 2000. Meat Science. Cabi Publishing, New York. 310 pp.

Wheeler, T.L., S.D. Schakelford, L.P. Johnson, M.F. Miller, R.K. Miller, and M. Koohmaraie. 1997. A comparison of Warner-Bratzler shear force assessment within and among institutions. Journal of Animal Science 75: 2423-2432. 